\title{
Effects of bovine pituitary growth hormone alone or in combination with the $\beta$-agonist clenbuterol on muscle growth and composition in veal calves
}

\author{
BY C. A. MALTIN, M. I. DELDAY, S. M. HAY, G. M. INNES \\ AND P. E. V. WILLIAMS \\ Rowett Research Institute, Greenburn Road, Bucksburn, Aberdeen AB2 9SB
}

(Received 11 August 1989 - Accepted 30 November 1989)

\begin{abstract}
Twenty-three British Friesian bull calves at approximately $7 \mathrm{~d}$ of age were allocated to one of four treatments: controls untreated (five calves), a group (Clen) given $1 \mathrm{mg}$ clenbuterol $/ \mathrm{kg}$ diet (five calves), a group (GH) given a daily subcutaneous injection of $3.5 \mathrm{mg}$ bovine pituitary growth hormone (GH) (five calves) and a group (Clen + GH) given a combination of clenbuterol as in the Clen group with $\mathbf{G H}$ as in the GH group (seven calves). All calves were given milk-substitute at levels adjusted weekly according to metabolic live weight. The animals were slaughtered over the weight range $150-170 \mathrm{~kg}$. Samples of semimembranosus and triceps muscles were excised at slaughter. Treatment with GH produced approximately a threefold increase in mean daily serum $\mathrm{GH}$ concentration. Calves given $\mathrm{Clen}+\mathrm{GH}$ were heaviest at slaughter and the combined treatment produced a significantly higher $(P<0-01)$ feed conversion ratio. Administration of clenbuterol either alone or in combination with $\mathrm{GH}$ increased the cross-sectional area of both fast twitch glycolytic (FG), and fast twitch oxidative glycolytic (FOG) fibres in both muscles. In contrast GH produced little change in fibre size in semimembranosus muscle, although FOG fibres in triceps were slightly larger than in controls. Neither Clen nor GH resulted in any change in fibre percentage frequency in either muscle. Treatments involving clenbuterol produced a significant decrease in muscle glycogen concentration. Muscles from all three treatment groups tended to show small increases in protein and RNA concentration compared with the controls. Muscles from animals treated with GH alone exhibited an increase in DNA concentration not seen in muscles from the two other treatment groups. Overall, the differential response to the two agents suggested that clenbuterol does not mediate its effects via the GH axis, and that an additive response in terms of protein anabolism may be achieved from the use of a combination of clenbuterol plus GH.
\end{abstract}

Clenbuterol: Growth hormone: Protein metabolism

The current trends in consumer food preferences stimulated by the association of excessive dietary lipid intake and incidence of coronary heart disease have increased the demand for lean meat. Agents such as the $\beta_{2}$-sympathomimetic, clenbuterol, have been used in a variety of species (Baker et al. 1984; Ricks, 1984; Reeds et al. 1986; Maltin et al. 1986; Williams, $1987 \mathrm{~b}$ ) to manipulate growth and body composition, enhancing the deposition of body protein and reducing fat, thereby being termed repartitioning agents. The mechanism of action of these agents with respect to protein deposition appears to involve reduced protein degradation and associated reduced nitrogen excretion, although a simultaneous increase in protein synthesis cannot be ruled out. Using hypophysectomized rats, James \& Barker (1987) identified that growth hormone (GH) was not essential to elicit protein anabolism with $\beta$-agonist treatment. It is well established that long-term administration of GH causes significant increases in muscle growth in pigs, cattle and lambs. Unlike the mechanism of action of anabolic steroids (Lobley et al. 1985) and apparently of some $\beta$-agonists (Reeds et al. 1986), GH stimulates protein synthesis (Eisemann et al. 1986; Pell \& Bates, 1987) and, in so doing, also raising $N$ retention. The 
fact that both $\beta$-agonists and $\mathrm{GH}$ possess protein anabolic activity but that the effect is achieved via apparently different mechanisms leads to the possibility that an additive effect could be achieved by their combined use. Preliminary results of this work were presented by Williams et al. (1987a) who demonstrated that combined administration of clenbuterol and bovine $\mathrm{GH}$ produced an additive effect with respect to protein deposition in growing veal calves.

The present communication reports more detail of the observed effects of the combined administration of clenbuterol and bovine $\mathrm{GH}$ to growing veal calves.

\section{MATERIAL AND METHODS}

The protocol of the present experiment was essentially that employed by Williams et al. $(1987 \mathrm{~b})$ in earlier work in which the effects of clenbuterol alone on the growth of veal calves, as a model for the bovine, were first examined. The design of the experiment was based on comparative slaughter, to accommodate measurements of energy and $\mathrm{N}$ retention over a fixed weight range.

\section{Animals}

Twenty-three British Friesian bull calves were purchased locally at approximately $7 \mathrm{~d}$ of age (day 7). Calves were purchased at weekly intervals in groups of four, with a final group of three. They were allocated to one of four treatments such that treatment groups were balanced for initial live weight: controls untreated (five calves); clenbuterol treated (Clen), given $1 \mathrm{mg}$ clenbuterol $/ \mathrm{kg}$ diet (five calves); growth hormone treated $(\mathrm{GH})$, given a daily subcutaneous injection: of $3.5 \mathrm{mg}$ bovine pituitary $\mathrm{GH}$ (five calves) and those given a combination of clenbuterol plus $\mathrm{GH}(\mathrm{Clen}+\mathrm{GH})$ at the same dose levels as for Clen and $\mathrm{GH}$ (seven calves). Orie calf was slaughtered on arrival and values from this calf were combined with that from four calves slaughtered at the same age and which constituted an initial slaughter group in an earlier experiment (Williams et al. 1987b).

\section{Feeding and management}

The calves were housed in individual pens littered with straw. They were given milksubstitute at levels adjusted weekly according to metabolic live weight ( $\mathrm{LW}^{0.75}$ ). It was given from a bucket twice daily, at 09.00 and 17.00 hours, up to $105 \mathrm{~kg}$ live weight and subsequently three times daily, at $07.00,13.00$ and 17.00 hours. The feed was reconstituted in warm water $\left(38^{\circ}\right)$ to a concentration of $125 \mathrm{~g} / 1$, from $7 \mathrm{~d}$ of age to $90 \mathrm{~kg}$ live weight and to $215 \mathrm{~g} / 1$ thereafter. Two formulations of commercial milk-substitute were used and the feeding programme and chemical analyses of the feed are given in Table 1. Calves were weighed weekly after the morning feed and the quality of milk offered adjusted according to the recorded weight. Milk refusals were collected and recorded and water was constantly available. Clenbuterol (as the hydrochloride) was added daily to each feed of the reconstituted milk-substitute such that calves on clenbuterol treatments received $1 \mathrm{mg}$ clenbuterol/kg milk-substitute dry matter (DM). Bovine pituitary GH was solubilized by adding the hormone to a saline solution ( $7 \mathrm{~g}$ sodium chloride/1) containing $0.025 \mathrm{M}$-sodium bicarbonate plus 0.025 M-sodium carbonate (Peel et al. 1981). The hormone was readily soluble and was made up in an injection volume of $3.0 \mathrm{ml}$. Calves on $\mathrm{GH}$ treatments received $3.5 \mathrm{mg}$ bovine pituitary $\mathrm{GH}$ daily, injected subcutaneously in the region of the flank.

\section{Blood sampling}

Blood samples were obtained from four calves on each treatment when the calves reached $110 \mathrm{~kg}$ live weight. Each calf was fitted with a jugular catheter and hourly $10 \mathrm{ml}$ samples 
Table 1. Declared composition and chemical analysis of the milk-substitutes and feeding programme of the calves

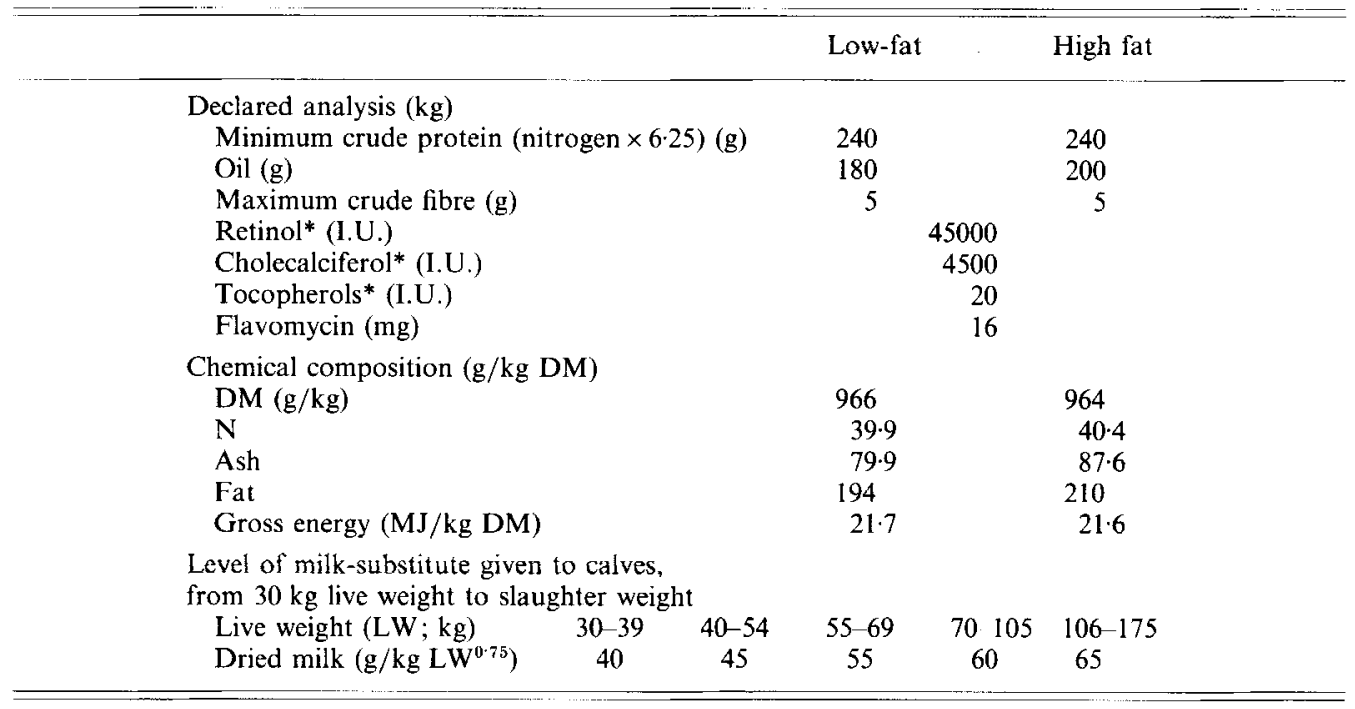

DM, dry matter.

* Source not declared.

of blood obtained over a $24 \mathrm{~h}$ period. Serum was obtained and stored frozen for subsequent analysis.

\section{Slaughter procedure}

The calves were slaughtered over the weight range $143-182 \mathrm{~kg}$, attempting to achieve the same mean slaughter weight for each treatment group. A range in slaughter weights was imposed so that differences in body composition at slaughter could be adjusted by covariance, using final live weights as the covariate. Adjustment was required to account for differences in mean final live weight at slaughter, since experience has shown that it is impossible to achieve the same mean live weight for groups of animals slaughtered at different times. Calves were slaughtered in a commercial abattoir using the methods previously described (Williams et al. 1987 b). Immediately after slaughter, samples of the triceps and semimembranosus muscles were removed, and frozen in liquid $\mathrm{N}_{2}$ for subsequent analysis. After slaughter and during dissection the contents of the alimentary tract were collected and weighed; gut-fill-corrected live weight was obtained by subtracting the weight of gut contents from the final live weight.

\section{Histochemistry}

Small samples of semimembranosus and triceps muscles were excised within $1 \mathrm{~min}$ of slaughter from all four groups of animals. The muscle samples were orientated for transverse sectioning, mounted on a small piece of cork, covered with OCT (optimal cutting temperature compound, Tissue Tek), and talcum powder and immediately frozen in liquid $\mathrm{N}_{2}$. The tissue was stored in liquid $\mathrm{N}_{2}$ until examined.

Transverse $10 \mu \mathrm{m}$ serial sections were cut in a cryostat (Frigocut; Reichert-Jung, Cambridge) and were reacted to demonstrate the presence of four enzymes: $\mathrm{Ca}^{2+}$-activated myofibrillar ATPase (EC 3.6.1.3, pH 10.4, a modification of the method of Hayashi \& Frieman (1966)), NADH-diaphorase (Pearse, 1972), $\alpha$-glycerophosphate dehydrogenase 
Table 2. The classification of fibre types in bovine skeletal muscle on the basis of histochemical reactions

\begin{tabular}{ccccc}
\hline & & & Stain & \\
Fibre type & $\begin{array}{c}\text { ATPase } \\
\text { pH } 10 \cdot 4\end{array}$ & NADH & GPOX & PHOS \\
\hline FOG & ++ &,+++++ &,+++++ &,+++++ \\
FG & +++ & + & +++ & +++ \\
SO & + & +++ & + & + \\
\hline
\end{tabular}

FOG, fast twitch oxidative glycolytic; FG, fast twitch glycolytic; SO, slow twitch oxidative; +++ , strong reaction; ++ , intermediate reaction; + , weak reaction; where a combination is used,+++++ reaction may lie between the two categories; ATPase, $\mathrm{Ca}^{2+}$-activated myofibrillar ATPase $(E C$ 3.6.1.3); NADH, NADHdiaphorase ( $E C$ 1.6.5.3); GPOX, glycerophosphate dehydrogenase (EC 1.1.99.5); PHOS, L-glucan phosphorylase (EC 2.4.1.97).

(EC 1.1.99.5) (Dubowitz \& Brooke, 1973) and L-glucan phosphorylase (EC 2.4.1.97) (Chayen et al. 1973). The fibre type composition was determined on the basis of the staining reaction in each fibre as outlined in Table 2 and the fibre nomenclature was based on that of Peter et al. (1972).

Fibre cross-sectional area was determined using a Hipad digitizing tablet (Bausch and Lomb) linked to a Prime 550 computer. Due to the size constraints it was not possible to carry out a total fibre count on the muscles. In addition to mean fibre area on a fibre-type basis, mean general fibre area was derived as weighted mean from the mean area of all fibres (irrespective of fibre type) (from muscles) within one dietary treatment. The measure is intended to give an idea of the general trends seen as a result of the different dietary treatments.

Relative area was calculated by multiplying the relative frequency of each individual fibre type by the mean area of that fibre type and expressing it as a percentage of the total sum of all fibre types.

\section{Biochemical analysis}

Samples of semimembranosus and triceps muscles taken within 1 min of slaughter were immediately frozen in liquid $\mathrm{N}_{2}$ and stored until analysis. Frozen muscle samples were powdered and known weights (approximately $200 \mathrm{mg}$ ) were homogenized in $0.5 \mathrm{M}-$ perchloric acid. Portions were then taken for the determination of glycogen (Keppler \& Decker, 1984), protein (Lowry et al. 1951), RNA (Munro \& Fleck, 1969), DNA (Burton, 1956), hydroxyproline (Firschein \& Shill, 1966) and creatine (Picou et al. 1976).

Serum GH concentrations were measured by a radioimmunoassay based on the method of Peake et al. (1979), using an anti-ovine GH serum (NIADDK-anti-oGH-2) and pure ovine GH antigen (NIADDK-oGH-I-3) supplied by the National Hormone and Pituitary Program, Baltimore, Maryland, USA.

\section{Muscles}

Semimembranosus and triceps muscles were selected for the study for two main reasons. First, the muscles were derived from hind- and fore-limb muscle groups respectively. Second, triceps is largely a mixed muscle, while semimembranosus comprises predominantly fast twitch. glycolytic (FG) fibres. Studies in rats (Maltin et al. 1986) have shown that there is a tendency for muscles to exhibit an increase in glycolytic capacity following clenbuterol treatment, thus the two muscles selected might be expected to show different responses to the treatments. 
Table 3. Effects on growth rate $(\mathrm{kg} / \mathrm{d})$, milk intake $(\mathrm{kg}$ dry matter $(\mathrm{DM}) / \mathrm{d})$ and feed conversion ratio (FCR; $\mathrm{kg}$ milk DM intake/ $\mathrm{kg}$ weight gain) of clenbuterol (20 $\mu \mathrm{g} / \mathrm{kg}$; Clen) or bovine growth hormone $(G H)$ given either alone or in combination to veal calves

\begin{tabular}{|c|c|c|c|c|c|c|}
\hline & \multicolumn{4}{|c|}{ Treatments groups* } & & \multirow{2}{*}{$\begin{array}{l}\text { Statistical } \\
\text { significance } \\
\text { of difference }\end{array}$} \\
\hline & Control & Clen & $\mathrm{GH}$ & Clen $+\mathrm{GH}$ & SED & \\
\hline No. of calves & 5 & 5 & 5 & 6 & & \\
\hline Initial live wt $(\mathrm{kg})$ & $44 \cdot 1$ & $43 \cdot 0$ & $43 \cdot 8$ & 42.5 & $2 \cdot 15$ & NS \\
\hline Gut-fill-corrected final wt $(\mathrm{kg})$ & 152.9 & 154.6 & 158.5 & $160 \cdot 9$ & 5.86 & NS \\
\hline Period on experiment (d) & 109 & 105 & 109 & 105 & 2 & NS \\
\hline Empty-body-wt gain (kg) & $108 \cdot 8$ & $111 \cdot 6$ & $114 \cdot 7$ & $118 \cdot 4$ & $6 \cdot 30$ & NS \\
\hline Live-wt gain $(\mathrm{kg} / \mathrm{d})$ & $0.99^{\mathrm{a}}$ & $1 \cdot 06^{\mathrm{ab}}$ & $1 \cdot 06^{\mathrm{ab}}$ & $1 \cdot 13^{\mathrm{b}}$ & 0.047 & $P<0.08$ \\
\hline Feed intake (kg DM) & 185 & 187 & 185 & 177 & 3.08 & NS \\
\hline FCR & $1 \cdot 70^{\mathrm{a}}$ & $1.68^{\mathrm{a}}$ & $1.61^{\mathrm{an}}$ & $1 \cdot 50^{\mathrm{b}}$ & 0.078 & $P<0.05$ \\
\hline
\end{tabular}

NS, not significant.

a,b Means within rows with different superscript letters were significantly different at the levels shown.

* For details, see p. 536 .

\section{Statistical analysis}

Data (except those for relative frequency and relative area) were assessed by analysis of variance procedures. Relative frequency and area were assessed by regression analysis with a Poisson error structure.

\section{RESULTS}

Daily injections of $\mathrm{GH}$ produced a threefold increase in blood serum GH concentrations in the calves, from a daily mean (mean of twenty-four samples obtained at hourly intervals) of 4.23 (SE 0.28$) \mathrm{ng} / \mathrm{ml}$ in the controls to $10 \cdot 8(\mathrm{SE} 1 \cdot 2) \mathrm{ng} / \mathrm{ml}$ in the group given $\mathrm{GH}$ alone and 15.3 (SE 2.29) $\mathrm{ng} / \mathrm{ml}$ in the group given the combined treatment. GH concentration in calves given only clenbuterol was $5 \cdot 31(\mathrm{SE} 1 \cdot 22) \mathrm{ng} / \mathrm{ml}$.

\section{Feed intake, live-weight gain and feed conversion ratio}

There were no significant differences between treatment groups in the mean age of the calves at the start of treatment ( $7 \mathrm{~d}$ of age) or at slaughter (mean age 107 (SE 2) d). Calves given the combined clenbuterol plus GH treatment were heaviest at slaughter but the differences failed to achieve significance (Table 3). There was a tendency for total feed consumed to be less in calves given Clen $+\mathrm{GH}$ compared with the other groups (177v. 186 $\mathrm{kg}$ milk-substitute DM) which was mainly due to a faster rate of gain of these calves compared with animals on the remaining treatments, especially during the second half of the trial. This, together with the non-significant higher rate of gain in these calves, produced a significantly higher $(P<0.05)$ feed conversion ratio $(\mathrm{kg}$ feed intake $/ \mathrm{kg}$ weight gain) in calves given the combined treatment compared with the controls (Table 4).

\section{Muscle-fibre variables}

Size. The overall effects are highlighted when the mean general fibre area is considered. In comparison with controls, semimembranosus from animals in the Clen and Clen $+\mathrm{GH}$ groups showed 50 and $60 \%$ increases respectively in mean general fibre area. In contrast, values from triceps of the Clen group suggested that clenbuterol was less effective, giving rise to a $13 \%$ increase in mean general fibre area, whereas, similar to values from semimembranosus, triceps from animals in the Clen $+\mathrm{GH}$ group showed a $49 \%$ increase in mean general fibre area. 


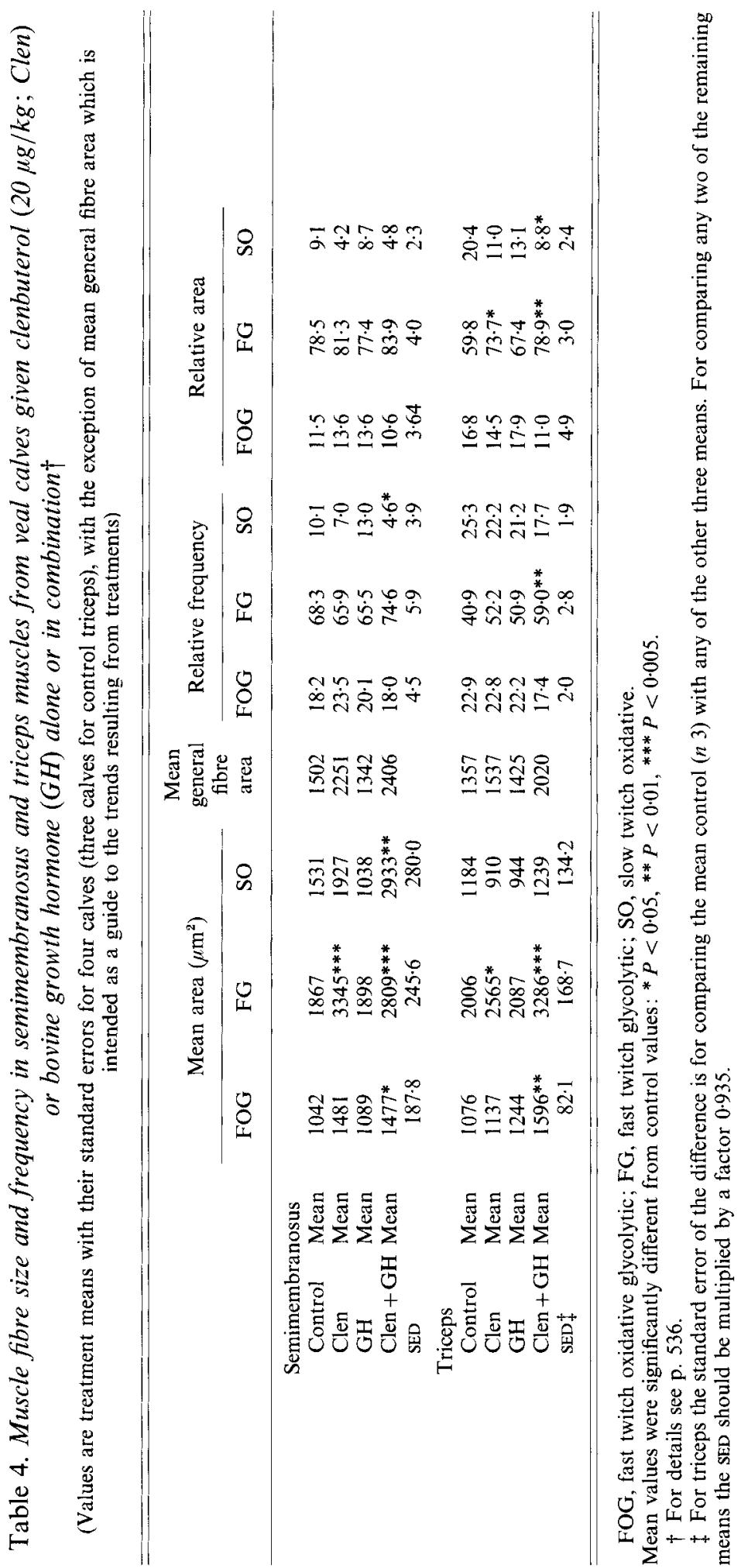


Administration of clenbuterol either alone or in combination with GH significantly increased the mean cross-sectional area of FG fibres in both triceps $(P<0.05)$ and semimembranosus muscles $(P<0.005$; Plate 1$)$. The combined treatment also resulted in an increase in the mean cross-sectional area of fast oxidative glycolytic (FOG) fibres in both muscles. In addition, in semimembranosus the $\mathrm{Clen}+\mathrm{GH}$ treatment gave rise to a significant increase in the area of slow oxidative (SO) fibres (Table 4).

In contrast, treatment with GH alone produced little change in fibre size in semimembranosus (Plate 1; Table 4), although in triceps FOG fibres were slightly larger than in controls (Plate 1; Table 4).

Frequency. Neither treatment with clenbuterol nor GH alone resulted in any change in fibre percentage frequency in either muscle (Table 4). The combined treatment, however, resulted in an increase in FG fibre frequency (significant in triceps) and a decrease in SO fibre frequency (significant in semimembranosus) in both muscles. The increase in FG frequency appeared to occur at the expense of FOG and SO fibres.

Percentage area. The changes in fibre area and frequency of specific fibre types were in the same direction and they were, therefore, clearly reflected in changes in percentage area. In particular, for triceps the changes in percentage area of FG and $\mathrm{SO}$ fibres in muscles from the $\mathrm{Clen}+\mathrm{GH}$ treatment group were statistically significant (cf. controls). Although a similar increase in FG and decrease in SO percentage area occurred in semimembranosus the changes did not reach statistical significance.

Statistical analysis suggested that, as for frequency, there was some evidence of specific fibre sensitivity to treatment. In triceps this was seen in the FG response to overall clenbuterol treatment $(P<0.01)$, while in semimembranosus it was the SO fibres which were most sensitive $(P<0 \cdot 05)$. There was, however, no evidence of any specific fibre-type sensitivity to $\mathrm{GH}$ treatment in either muscle.

\section{Biochemical analysis (Table 5)}

Muscles from the three treatment groups showed few statistically significant differences from the controls (Table 5). However, there were some consistent trends worthy of comment. In particular, both triceps and semimembranosus muscles from all three treatment groups showed a small increase in protein (with the exception of semimembranosus from the Clen $+\mathrm{GH}$ group) and RNA concentrations compared with untreated control muscles (Table 5). In addition, muscles from animals treated with GH alone exhibited an increase in DNA concentration not evident in muscles from the other two treatment groups.

Treatments involving clenbuterol (either alone or in combination with $\mathrm{GH}$ ) were notable in producing a considerable decrease in muscle glycogen concentration. This reduction in glycogen was statistically significant in triceps but not in semimembranosus.

\section{DISCUSSION}

The sympathomimetic nature of clenbuterol was highlighted by the depletion of muscle glycogen and was consistent with observations from lambs treated with another $\beta$-agonist, cimaterol (McEwan et al. 1985). This result also correlates well with the increase in the apparent capacity of the muscle to metabolize glycogen (as estimated from the increase in the percentage area of FG fibres in both triceps and semimembranosus) following clenbuterol treatment. Depletion of muscle glycogen reserves before slaughter in animals treated with $\beta$-agonists presents a problem for the commercial use of these agents as growth promoters. Loss of muscle glycogen restricts the normal fall in muscle $\mathrm{pH}$, as described by Beermann et al. (1985) in sheep treated with climaterol, and may lead to dark-cutting meat. 
Table 5. Composition of semimembranosus and triceps muscle in veal calves given clenbuterol $(20 \mu \mathrm{g} / \mathrm{kg}$; Clen) or bovine growth hormone $(G H)$ alone or in combination*

(All values are expressed per unit frozen muscle)

\begin{tabular}{|c|c|c|c|c|c|}
\hline & Control & Clen & GH & $\mathrm{Clen}+\mathrm{GH}$ & SED \\
\hline No. of calves ... & 5 & 4 & 5 & 6 & \\
\hline \multicolumn{6}{|l|}{ Semimembranosus } \\
\hline Protein $(\mathrm{mg} / \mathrm{g})$ & $167 \cdot 0$ & $180 \cdot 0$ & $177 \cdot 0$ & 163.6 & 7.03 \\
\hline RNA $(\mu \mathrm{g} / \mathrm{mg})$ & 0.463 & 0.508 & 0.483 & 0.517 & 0.0401 \\
\hline DNA $(\mu \mathrm{g} / \mathrm{mg})$ & $0 \cdot 348^{\mathrm{a}, \mathrm{b}}$ & $0 \cdot 314^{\mathrm{a}}$ & $0 \cdot 367^{\mathrm{a}, \mathrm{b}}$ & $0.273^{b}$ & 0.0311 \\
\hline Creatine $(\mu \mathrm{g} / \mathrm{mg})$ & $4 \cdot 23$ & $4 \cdot 00$ & 4.29 & 3.91 & 0.201 \\
\hline Hydroxyproline (mg/mg) & $0 \cdot 213^{a}$ & $0.224^{\mathrm{a}}$ & $0.285^{\mathrm{a}, \mathrm{b}}$ & $0 \cdot 310^{\mathrm{b}}$ & 0.0387 \\
\hline Glycogen $(\mu \mathrm{mol}$ glucosyl $\mathrm{U} / \mathrm{g} w \mathrm{wt})$ & $60 \cdot 9$ & $58 \cdot 6$ & $61 \cdot 7$ & $50 \cdot 9$ & $9 \cdot 151$ \\
\hline \multicolumn{6}{|l|}{ Triceps } \\
\hline Protein $(\mathrm{mg} / \mathrm{g})$ & $162 \cdot 2$ & $175 \cdot 3$ & $171 \cdot 3$ & $175 \cdot 2$ & 7.03 \\
\hline RNA $(\mu \mathrm{g} / \mathrm{mg})$ & 0.433 & 0.499 & 0.528 & 0.517 & 0.0679 \\
\hline DNA $(\mu \mathrm{g} / \mathrm{mg})$ & $0 \cdot 354^{\mathrm{a}}$ & $0.303^{\mathrm{a}, \mathrm{b}}$ & $0.456^{\mathrm{c}}$ & $0.276^{\mathrm{b}}$ & 0.0349 \\
\hline Creatine $(\mu \mathrm{g} / \mathrm{mg})$ & 3.52 & 3.87 & 3.57 & 3.73 & 0.226 \\
\hline Hydroxyproline (mg/mg) & $0 \cdot 201^{a, b}$ & $0 \cdot 164^{\mathrm{a}}$ & $0 \cdot 222^{\mathrm{b}}$ & $0 \cdot 240^{\mathrm{b}}$ & 0.0255 \\
\hline Glycogen $(\mu \mathrm{mol}$ glucosyl U/g wt) & $81 \cdot 4^{\mathrm{a} \cdot \mathrm{b}}$ & $51 \cdot 6^{\mathrm{b}}$ & $84 \cdot 8^{\mathrm{a}}$ & $59 \cdot 0^{\mathrm{b}}$ & 11.085 \\
\hline
\end{tabular}

NS, not significant.

$\mathrm{a}, \mathrm{b}, \mathrm{c}$ Means within rows with different superscript letters were significantly different: $P<0.05$.

* For details, see p. 536.

The significant hypertrophy of FG fibres in the Clen group is consistent with observations in rat extensor digitorum longus muscles. Whilst hypertrophy of FOG fibres failed to reach significance, these results compare with the FOG hypertrophy demonstrated in rat soleus muscle (Maltin et al. 1986). Our results reported here and those of Maltin et al. (1986) are in agreement with those of Kim et al. (1987), but tend to conflict with those of Beermann et al. (1985) where, in sheep, increases in both type I (slow twitch) and type II (fast twitch) fibres were reported. Kim et al. (1988) also reported that the muscles responded to differing degrees, with responses greater in the plantaris compared with the soleus muscle. Kim et al. (1988) suggested that factors such as length of treatment period and breed may be responsible for treatment differences in the responsiveness of individual muscles to $\beta$-agonist treatment, and also suggested that the growth-promoting effect of cimaterol is sustained longer in older than in younger animals. Comparing the results of Maltin et al. (1986) and Kim et al. (1988) it appears that young rats (23-24 d of age) treated with clenbuterol shoved a high degree of muscle specificity in response to $\beta$-agonist treatment (Maltin et al. 1986), whereas this specificity was much reduced when older rats were treated at either 45 or $100 \mathrm{~d}$ of age albeit with a different $\beta$-agonist, cimaterol (Kim et al. 1988). A similar conclusion may be drawn when comparing the lamb values obtained by Beermann et al. (1985) and our calf values; in lambs treated at $28 \mathrm{~kg}$ live weight (approximately $70 \mathrm{~d}$ of age and 0.5 of mature body-weight) there was little discrimination between the fibres which responded whereas in calves treated from approximately $10 \mathrm{~d}$ of age for a period of approximately $107 \mathrm{~d}$, i.e. they had only reached approximately 0.25 of mature body-weight at slaughter, there was again a highly selective response.

The effects of clenbuterol on muscle fibre area contrasts with the effects of GH which, in these calves, did not influence the mean fibre area. Increased body-weight gain was obtained over a similar weight range to that used in the present experiment in calves treated with $25 \mu \mathrm{g} / \mathrm{kg}$ body-weight of a recombinant-derived bovine GH (Kirchgessner et al. 1987), indicating that young calves are capable of responding to exogenous $\mathrm{GH}$. If $100 \mathrm{~kg}$ is taken 
as approximating to the mean weight of the calves over the duration of the present trial, then the mean level of $\mathrm{GH}$ administration was $35 \mu \mathrm{g} / \mathrm{kg}$ body-weight, although the dose level varied from 80 to $22 \mu \mathrm{g} / \mathrm{kg}$ body-weight at the start and end of the trial when the mean live weights of the calves were 40 and $160 \mathrm{~kg}$ respectively. This declining level of $\mathrm{GH}$ administration, as the age and live weight of the calves increased may be significant in explaining the lack of response, since it resulted in the minimum level of $\mathrm{GH}$ administration when it would be expected that the calves were most responsive. Breir et al. $(1988 a, b)$ have identified both nutritional and age-related interactions in the response of young calves to exogenous $\mathrm{GH}$, but their results suggest that milk-fed calves would be capable of responding to exogenous $\mathrm{GH}$. Hence, the apparent lack of a major response in this present experiment is rather surprising.

Combined treatment with clenbuterol and GH produced fibre hypertrophy in all three types. In addition to the FG hypertrophy seen in both muscles with clenbuterol alone, hypertrophy was evident in SO and FOG fibres and was suggestive of an interaction between the two treatments. The basis for this additional hypertrophy is not clear but may warrant further investigation.

Although there were few significant differences in muscle composition, the trends in RNA and DNA content were consistent with values reported in the literature. Increases in RNA concentration as a result of $\beta$-agonist treatment have been reported (Beermann et al. 1985; Kim et al. 1988) and also as a result of GH treatment (Pell \& Bates, 1987). In both the semimembranosus and triceps muscles of calves, clenbuterol and GH alone or in combination tended to increase muscle RNA in a manner consistent with the increase in protein. In both muscles the DNA concentration was elevated by treatment with GH alone but was significantly reduced in the combined treatment group. From these findings it might be speculated that the increases in protein and RNA in the absence of a change in DNA suggest that the anabolic effects of clenbuterol were mediated through hypertrophy. In contrast an increase in DNA suggests that those of $\mathrm{GH}$ were expressed by way of hyperplasia.

The protein anabolic effects of clenbuterol and GH may be achieved through different mechanisms. For example, work on both rats (Reeds et al. 1986) and calves (Williams et al. $1987 \mathrm{~b}$ ) suggested that clenbuterol produced a depression of protein degradation rates with little or no change in synthesis. In contrast both Emery et al. (1984) and Pell \& Bates (1987) demonstrated an increase in protein synthesis rates with no change in degradation in muscles from clenbuterol-treated animals. However, Maltin et al. (1989) has shown that clenbuterol treatment of innervated and denervated phasic extensor digitorum longus, plantaris and gastrocnemius muscles from rats whilst still affecting protein degradation increased the fractional rate of protein synthesis, but the temporal response varied and the response was muscle specific. With respect to GH, Pell \& Bates (1987) demonstrated a concomitant increase in the rates of both protein synthesis and degradation. On the other hand Eisemann et al. (1986) showed increased $\mathrm{N}$ retention, lower $\mathrm{N}$ excretion and no change in urinary excretion of methylhistidine or hydroxyproline which might indicate an action entirely on protein synthesis. Thus, the difference in response in terms of muscle protein anabolism to $\beta$-agonists and GH suggests that a greater effect could be achieved by a combination of the two treatments compared with either used individually. In the present study (with the exception of FG fibres in semimembranosus) the combined treatments gave rise to changes in muscle fibre size which were greater than with either treatment alone. Hence, the present findings and those from Williams et al. (1987a) and Pell \& Bates (1987) in which the two substances were administered together support this contention. Pell \& Bates (1987) also showed that the anabolic effect of clenbuterol and GH in combination was via an increase in protein synthesis attributable to each substance individually and 
which was mediated through increases in RNA concentration. In the present study no measure of protein turnover was made; it is, therefore, not possible to comment on the mechanism behind the effect of combined treatment. However, in contrast to the observations of Pell \& Bates (1987), in the present study the changes in RNA concentration observed were rather small, which suggests that there might not have been a significant change in synthesis. The majority of the studies in which mechanisms have been discussed (Reeds et al. 1986; Pell \& Bates, 1987) have been carried out over a short time-scale; in the present study calves were exposed to the treatments for approximately $100 \mathrm{~d}$. It is, therefore, possible that the present findings represent the outcome of changes in protein metabolism which occurred early in the treatment period. This appeared to occur in rats (Reeds et al. 1988) in which the response to clenbuterol was elicited in the first week of treatment and arose as a stepwise increase in the growth rate and protein content of the muscles.

Thus, the results of the present study suggest that administration of clenbuterol either alone or in combination with GH leads to an increase in muscle fibre size. While some of the findings on fibre-type hypertrophy may indicate some interaction between the two treatments, no such evidence was obtained from the compositional values. This leads to the general conclusion that the action of clenbuterol is not mediated via the GH axis.

The authors are most grateful to Dr S. James of Coopers Animal Health, Berkamsted, Hertfordshire for the generous gifts of clenbuterol and bovine growth hormone. The statistical advice of Mrs H. M. Vint is also acknowledged.

\section{REFERENCES}

Baker, P. K., Dalrymple, R. H., Ingle, D. \& Ricks, C. A. (1984). Use of a $\beta$-agonist to alter muscle and fat deposition in lambs. Journal of Animal Science 59, 1256-1261.

Beermann, D. H., Fischell, V. K., Hogue, D. H. \& Dalrymple, C. A. (1985). Effects of cimaterol (CL263, 708) and fishmeal on post mortem $\mathrm{pH}$, tenderness and colour in lamb skeletal muscle. Journal of Animal Science 61, Suppl. 1, 271.

Breir, B. H., Gluckman, P. D. \& Bass, J. J. (1988a). Influence of nutritional status and oestradiol-17 $\beta$ on plasma growth hormone, insulin-like growth factors- 1 and -II and the response to exogenous growth hormone in young steers. Journal of Endocrinology 118, 243-250.

Breir, B. H., Gluckman, P. D. \& Bass, J. J. (1988 b). Plasma concentrations of insulin-like growth factor-I and insulin in the infant calf: ontogeny and influence of altered nutrition. Journal of Endocrinology 119, 43-50.

Burton, K. (1956). A study of the conditions and mechanisms of the diphenylalamine reaction for the colorimetric estimation of dioxyribonucleic acid. Journal of Biochemistry 62, 315-323.

Chayen, J., Bitensky, L. \& Butcher, R. G. (1973). Practical Histochemistry, pp. 158-162. New York: John Wiley \& Sons.

Dubowitz, K. \& Brooke, M. H. (1973). Muscle Biopsy: a Modern Approach, vol. 2. p. 31. London: W. B. Saunders.

Eisemann, J. H., Hammond, A. C., Bauman, D. E., Reynolds, P. J., McCutcheon, S. N., Tyrrell, H. F. \& Haaland, G. L. (1986). Effect of bovine growth hormone administration on metabolism of growing Hereford heifers: protein and lipid metabolism and plasma concentrations of metabolites and hormones. Journal of Nutrition 116, 2504-2515.

Emery, P. W., Rothwell, N. J., Stock, M. J. \& Winter, P. D. (1984). Chronic effects of $\beta 2$-adrenergic agonists on body composition and protein synthesis in the rat. Bioscience Reports 4, 83-91.

Firschein, H. E. \& Shill, J. P. (1966). The determination of total hydroxyproline in urine and bone extracts. Analytical Biochemistry 14, 296-304.

Hayashi, M. \& Frieman, D. G. (1966). An improved method of fixation for formalin sensitive enzymes, with special reference to myosin adenosine triphosphatase. Journal of Histochemical Cytochemistry 4, 577-581.

James, S. \& Barker, H. D. (1987). Effect of clenbuterol on the growth and carcass composition of hypophysectomised rats in the presence or absence of growth hormone. Proceedings of the Nutrition Society 46, 108A.

Keppler, D. \& Decker, K. (1984). Glycogen. In Methods in Enzymatic Analysis, 3rd ed, vol. 6, pp. 11-19. [H., V., Bergmeyer, editor]. Florida and Basel: Verlag Chemie Weinheim.

Kim, Y. S., Lee, Y. B. \& Ashmore, C. R. (1988). Cimaterol induced growth in rats: growth pattern and biochemical characteristics. Growth, Development and Aging 52, 41-46. 
British Journal of Nutrition, Vol. 63 No. 3

Plate 1
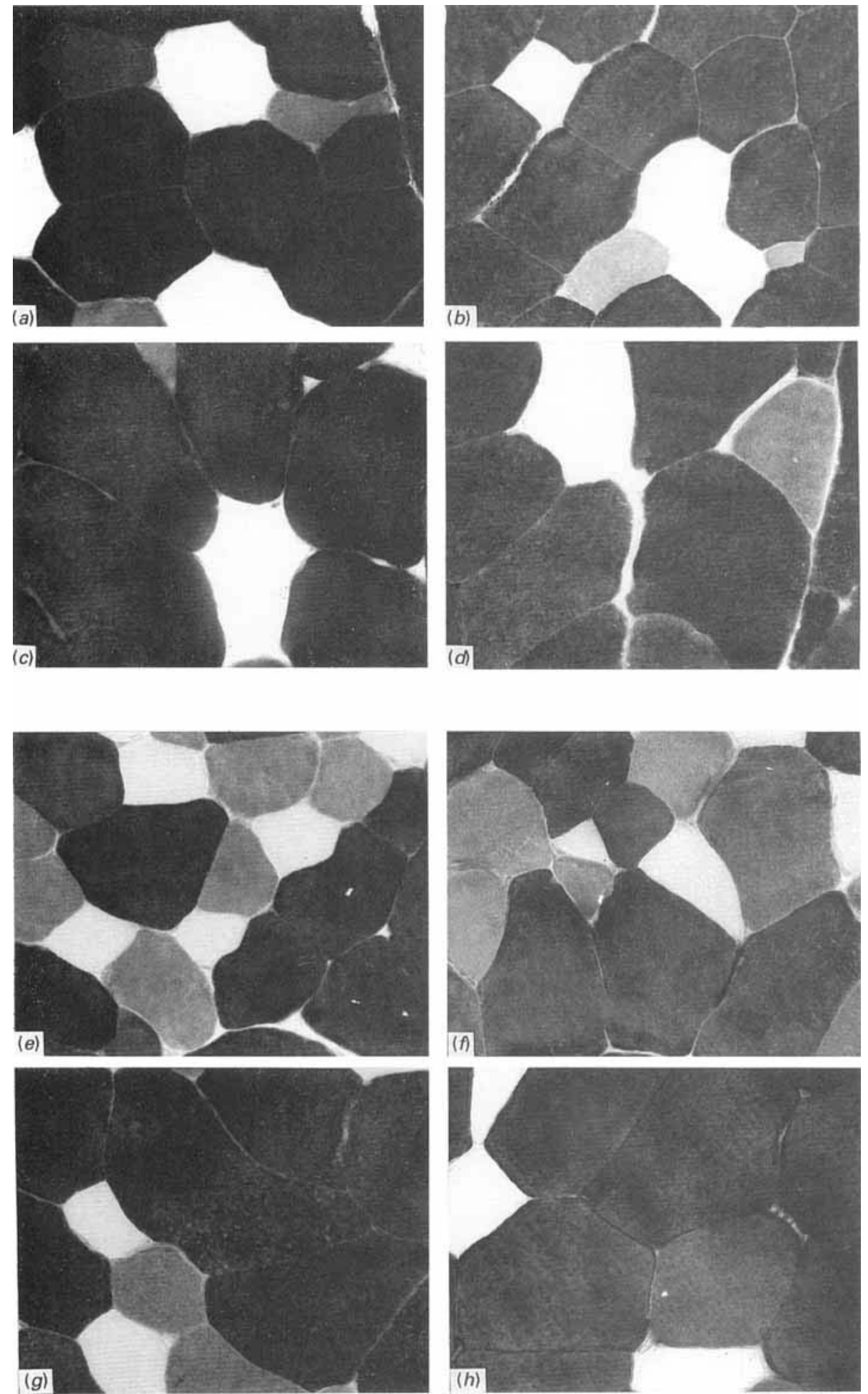
Kim, Y. S., Lee, Y. B. \& Dalrymple, R. H. (1987). Effect of the repartitioning agent cimaterol on growth, carcass and skeletal muscle characteristics in lambs. Journal of Animal Science $\mathbf{6 5}, 1392-1399$.

Kirchgessner, M., Roth, F. X., Schams, D. \& Karg, H. (1987). Influence of exogenous growth hormone (GH) on performance and plasma GH concentrations of female veal calves. Journal of Animal Physiology and Animal Nutrition 58, 50-59.

Lobley, G. E., Connell, A., Mollison, G. S., Brewer, A., Harris, C. I. \& Buchan, V. (1985). The effects of a combined implant of trenbolone acetate and oestradiol- $17 \beta$ on protein and energy metabolism in growing beef steers. British Journal of Nutrition 54, 681-694.

Lowry, O. H., Rosebrough, N. J., Farr, A. L. \& Randall, R. J. (1951). Protein measurement with the folin phenol reagent. Joumal of Biological Chemistry 193, 265-275.

McEwan, J. C., Hanrahan, J. P., Fitzsimons, J. M., Tarrant, P. V. \& Allen, P. (1985). Effects of the $\beta$-agonist cimaterol on growth, carcass composition and blood metabolites in ram lambs of three breeds. Research Report. An Foras Taluntais. Animal Production Research Report 7-8.

Maltin, C. A., Delday, M. I. \& Reeds, P. J. (1986). The effect of a growth promoting drug, clenbuterol, on fibre frequency and area in hind limb muscles from young male rats. Bioscience Reports 6, 293-299.

Maltin, C. A., Hays, S. M., Delday, M. I., Lobley, G. E. \& Reeds, P. J. (1989). The effect of the $\beta$-agonist clenbuterol on protein metabolism in innervated and denervated phasic muscles. Journal of Biochemistry $\mathbf{2 6 1}$, $965-971$.

Munro, H. N. \& Fleck, A. (1969). Analysis of tissues and body fluids for nitrogenous constituents. Mammalian Protein Metabolism, vol. 3, pp. 423-525 [H. N. Munro, editor]. New York: Academic Press.

Peake, G. T., Morris, J.\& Buckman, M. T. (1979). Growth hormone. In Methods of Hormone Radioimmunoassay, 2nd ed, pp. 223-244 [B. M. Jaffe and H. R. Behrman, editors]. London: Academic Press.

Pearse, A. G. E. (1972). Histochemistry, Theoretical and Applied, 3rd ed, p. 1342. London: Churchill-Livingstone.

Peel, C. J., Bauman, D. E., Gorewitt, R. C. \& Sniffen, J. (1981). Effect of exogenous growth hormone on lactational performance in high yielding dairy cows. Journal of Nutrition 111, 1662-1671.

Pell, J. M. \& Bates, P. C. (1987). Collagen and non-collagen protein turnover in skeletal muscle of growth hormone-treated lambs. Journal of Endocrinology 115, R1-R4.

Peter, J. B., Barnard, R. J., Edgerton, V. R., Gillespie, C. A. \& Stempel, K. E. (1972). Metabolic profiles of three fibre types of skeletal muscle in guinea pigs and rabbits. Biochemistry 11, 2627-2633.

Picou, D. I. M., Reeds, P. J., Jackson, A. A. \& Poulter, N. R. (1976). The measurement of muscle mass in children with ${ }^{15} \mathrm{~N}$-creatine. Paediatric Research 10, 184-188.

Reeds, P. J., Hay, S. M., Dorward, P. M. \& Palmer, R. M. (1986). Stimulation of muscle growth by clenbuterol: lack of effect of muscle protein biosynthesis. British Journal of Nutrition 56, 249-258.

Reeds, P. J., Hay, S. M., Dorward, P. M. \& Palmer, R. M. (1988). The effect of $\beta$-agonists and antagonists on muscie growth and body composition of young rats. Comparative Biochemistry and Physiology 89C, 337--341.

Ricks, C. A., Dalrymple, R. M., Baker, D. K. \& Ingle, D. L. (1984). Use of a $\beta$-agonist to aiter fat and muscle deposition in steers. Journal of Animal Science 59, 1247-1255.

Williams, P. E. V., Ogden, K.\& James, S. (1987a). The effects of a combination of the $\beta$-agonist (clenbuterol) and bovine pituitary growth hormone on growth of milk-fed calves. Animal Production 44, 474.

Williams, P. E. V., Pagliani, L., Innes, G. M., Pennie, K. \& Garthwaite, P. $(1987 b)$. Effects of a $\beta$-agonist (clenbuterol) on the growth, carcass composition, protein and energy balance of veal calves. British Journal of Nutrition 57, 417-428.

\section{EXPLANATION OF PLATE}

Plate 1. Transverse cross-sections of muscle reacted to demonstrate $\mathrm{Ca}^{2+}$-activated myofibrillar ATPase (EC 3.6.1.3) activity. $(a-d)$, Semimembranosus from animals in the following treatment groups: $(a)$, control; $(b)$, growth hormone; $(c)$, clenbuterol; $(d)$, clenbuterol + growth hormone. $(e-h)$, Triceps from animals in the following treatment groups: $(e)$, control; $(f)$, growth hormone; $(g)$, clenbuterol; $(h)$, clenbuterol + growth hormone. For details of treatments, see p. $536 .-50 \mu \mathrm{m}$. 